\title{
Effect of harmones on callus induction in Maize (Zea mays $L$.
}

\author{
N. Malini*, C. R. Anandakumar, R. Gnanam and S. Hari Ramakrishnan \\ Plant Breeding and Genetics, Agricultural Research Station, Tamil Nadu Agricultural University, Kovilpatti - 624 \\ 501 (Tamil Nadu), INDIA \\ *Corresponding author. E-mail: malinipbg200201@gmail.com
}

Received: August 1, 2017; Revised received: September 22, 2017; Accepted: January 25, 2018

\begin{abstract}
Callus induction from explants is a critical process in regeneration, micropropagation and transformation of maize (Zea mays L.) plants. Formation of callus from plant tissues on culture is affected by several factors. This study revealed to establish the effect of genotype, source of explants and auxin concentration on callus induction from five genotypes UMI $757(\mathrm{G} 1)$, UMI $615\left(\mathrm{G}_{2}\right)$, UMI $112\left(\mathrm{G}_{3}\right)$, UMI $285\left(\mathrm{G}_{4}\right)$ and $\mathrm{CO} 1\left(\mathrm{G}_{5}\right)$ and one hybrid $\mathrm{CO} H$ (M) $5\left(G_{6}\right)$. Callus induction of the six maize varieties was investigated using immature embryos $\left(E_{1}\right)$, leaf bits $\left(E_{2}\right)$, root tips $\left(E_{3}\right)$, hypocotyls $\left(E_{4}\right)$ and seeds $\left(E_{5}\right)$ as explants with different concentrations of hormones. In this study, immature embryo was taken from 10 to 12 days after pollination (DAP) to get maximum response. The highest percentage of callus induction was observed (99.10) in immature embryo culture and seed culture gave the highest percentage of rhizogenic callus formation when compare to immature embryo. Among the genotypes tested, $\mathrm{CO} \mathrm{H}$ (M) 5 recorded the highest callus induction percentage on (2D2K2) medium composition.
\end{abstract}

Keywords: Callus induction, Hormones, Immature embryo, Maize, Seed.

\section{INTRODUCTION}

Maize (Zea mays L.) with $2 \mathrm{n}=20$, is the third most widely distributed crop of the world after Rice and Wheat (Devi, et al., 2016) being grown in diverse seasons and ecologies with highest production and productivity among food cereals. It is an important source of carbohydrate, protein, iron, vitamin B and minerals ( $\mathrm{P}$ and $\mathrm{K})$. In Sudan, maize is produced using traditional or mechanical methods and is mainly used for food, forage and is a potential source of foreign exchange through export (Omer et al., 2008). Maize production is affected by biotic and a biotic factors. There constraints can be overcome through development of varieties that can tolerate (or) resist the stress. This can be done through complementing conventional breeding and genetic transformation. Success in plant transformation is dependent on the ability to regenerate a whole plant from transformed tissue (Ahmadabadi et al., 2007) plant regeneration through tissue culture of maize was first reported by Green and Philips (1975). Agrobacterium mediated transformation of maize needs efficient regeneration systems. In this study, six maize genotypes were evaluated for their response to tissue culture at different hormone concentrations using five different explants sources.

\section{MATERIALS AND METHODS}

Plant Materials: Seeds of maize (Zea mays L.) genotypes, UMI 757, UMI 615, UMI 112, UMI 285 and
$\mathrm{CO} 1$ and one hybrid $\mathrm{CO} \mathrm{H}$ (M) 5 were used in this study. These seeds were surface sterilized with $70 \%$ ethanol for 2 minutes followed by $0.1 \% \mathrm{HgCl}_{2}$ for 5 minutes and then washed with three to four times with sterilized distilled $\mathrm{H}_{2} \mathrm{O}$ under aseptic conditions. The sterile seeds were used as source of explants for callus induction. To establish plants to obtain leaf bits, root tip, Hypocotyl explants, sterile seeds were planted in sterile Jam jars containing MS basal salts (Murashige and Skoog, 1962). The Jar were kept in a growth room and maintained at a temperature of $28^{\circ} \mathrm{C}$ and sterile seeds. Immature embryo also used as explants. Immature embryos of 1.0- $2.0 \mathrm{~mm}$ size were aseptically excised from surface sterilised kernels. The Immature embryos were placed on the semisolid Ms medium with the rounded scutellar side exposed and the plant Plumule radical axis side in contact with the medium.

Preparation of callus induction: Callus induction were performed on MS medium comprising of MS salts and vitamins supplemented with Macronutrients, Micronutrients, Micronutrient and Vitamins, 3\% ( w/v) sucrose. The $\mathrm{pH}$ of the medium was adjusted to 5.6 to 5.8 with IM NaoH or $0.1 \mathrm{M} \mathrm{HCl}$ and $0.8 \%$ (w/v) agar added before autoclaving to sterilize. The sterilized medium was allowed to cool before adding 2.4-D. The medium was dispensed in sterile Petridishes in volumes of $30 \mathrm{ml}$ and allowed to solidity. Explants were cultured on the medium and plates sealed with parafilm. Sixteen levels of treatment combinations of 2,4-D and kinetin were tested to establish their efficacy in 
establishing callus from five different explants. The mature and healthy seeds of maize were taken for callus Induction. The seeds were sterilized with $70 \%$ ethanol for 2 min followed by 0.1 percent $\mathrm{Hg} \mathrm{Cl}_{2}$ for 5 min. Sterilized seeds were inoculated under aseptic conditions in the callus induction medium. The culture tubes were incubated in darkness at $25 \pm 2{ }^{\circ} \mathrm{C}$ for callus induction. The Immature embryo has proven to be the best source for the establishment of embryogenic callus and plant regeneration in maize. The Immature Embryo from maize cob were collected 10-16 days after pollination. The kernels were surface sterilized under Laminar Air Flow Chamber, the Immature embryos were aseptically excised from the kernels of the ear by cutting off kernels using scalpel blade and removing the endosperm. The immature embryo was placed on semisolid medium and was incubated for callus induction. About one $\mathrm{cm}$ explants were cut from seven day old seedlings collected from aseptically germinated seedlings. Inoculation of leaf bits, hypocotyls and roots were incubated on to the different callus Induction media, such as $\mathrm{T}_{1} \mathrm{MS}+0.5 \mathrm{mg} \mathrm{l}^{-1} 2,4-\mathrm{D}+$ $0.3 \mathrm{mg} \mathrm{l}^{-1} \mathrm{kin}+1 \mathrm{~g} \mathrm{l}^{-1} \mathrm{CH}, \mathrm{T}_{2} \mathrm{MS}+0.5 \mathrm{mg} \mathrm{l}^{-1} 2,4-\mathrm{D}$ $+0.2 \mathrm{mg} \mathrm{l}^{-1} \mathrm{kin}+1 \mathrm{~g} \mathrm{l}^{-1} \mathrm{CH}, \mathrm{T}_{3} \quad \mathrm{MS}+0.5 \mathrm{mg} \mathrm{l}^{-1} 2,4-$ $\mathrm{D}+0.1 \mathrm{mg} \mathrm{l}^{-1} \mathrm{kin}+1 \mathrm{~g} \mathrm{l}^{-1} \mathrm{CH}, \mathrm{T}_{4} \quad \mathrm{MS}+1.0 \mathrm{mg} \mathrm{l}^{-1} 2,4$ $-\mathrm{D}+0.3 \mathrm{mg} \mathrm{l}^{-1} \mathrm{kin}+1 \mathrm{~g} \mathrm{l}^{-1} \mathrm{CH}, \mathrm{T}_{5} \quad \mathrm{MS}+1.0 \mathrm{mg} \mathrm{l}^{-1}$ $2,4-\mathrm{D}+0.2 \mathrm{mg} \mathrm{l}^{-1} \mathrm{kin}+1 \mathrm{~g} \mathrm{l}^{-1} \mathrm{CH}, \mathrm{T}_{6} \mathrm{MS}+1.0$ $\mathrm{mg} \mathrm{l}^{-1} 2,4-\mathrm{D}+0.1 \mathrm{mg} \mathrm{l}^{-1} \mathrm{kin}+1 \mathrm{~g} \mathrm{l}^{-1} \mathrm{CH}, \mathrm{T}_{7} \mathrm{MS}+$ $1.5 \mathrm{mg} \mathrm{l}^{-1} 2,4-\mathrm{D}+0.3 \mathrm{mg} \mathrm{l}^{-1} \mathrm{kin}+1 \mathrm{~g} \mathrm{l}^{-1} \mathrm{CH}, \mathrm{T}_{8}$ $\mathrm{MS}+1.5 \mathrm{mg} \mathrm{l}^{-1} 2,4-\mathrm{D}+0.2 \mathrm{mg} \mathrm{l}^{-1} \mathrm{kin}+1 \mathrm{~g} \mathrm{l}^{-1} \mathrm{CH}$, $\mathrm{T}_{9} \quad \mathrm{MS}+1.5 \mathrm{mg} \mathrm{l}^{-1} 2,4-\mathrm{D}+0.1 \mathrm{mg} \mathrm{l}^{-1} \mathrm{kin}+1 \mathrm{~g} \mathrm{l}^{-1}$ $\mathrm{CH}, \mathrm{T}_{10} \mathrm{MS}+2.0 \mathrm{mg} \mathrm{l}^{-1} 2,4-\mathrm{D}+0.3 \mathrm{mg} \mathrm{l}^{-1} \mathrm{kin}+1 \mathrm{~g}$ $\mathrm{l}^{-1} \mathrm{CH}, \mathrm{T}_{11} \mathrm{MS}+2.0 \mathrm{mg} \mathrm{l}^{-1} 2,4-\mathrm{D}+0.2 \mathrm{mg} \mathrm{l}^{-1} \mathrm{kin}+$ $1 \mathrm{~g} \mathrm{l}^{-1} \mathrm{CH}, \mathrm{T}_{12} \mathrm{MS}+2.0 \mathrm{mg} \mathrm{l}^{-1} 2,4-\mathrm{D}+0.1 \mathrm{mg} \mathrm{l}^{-1} \mathrm{kin}$ $+1 \mathrm{~g} \mathrm{l}^{-1} \mathrm{CH}, \mathrm{T}_{13} \mathrm{MS}+0.5 \mathrm{mg} \mathrm{l}^{-1} \mathrm{IAA}+0.3 \mathrm{mg} \mathrm{l}^{-1} \mathrm{kin}$ $+1 \mathrm{~g} \mathrm{l}^{-1} \mathrm{CH}, \mathrm{T}_{14} \mathrm{MS}+1.0 \mathrm{mg} \mathrm{l}^{-1} \mathrm{IAA}+0.3 \mathrm{mg} \mathrm{l}^{-1}$ $\mathrm{kin}+1 \mathrm{~g} \mathrm{l}^{-1} \mathrm{CH}, \mathrm{T}_{15} \mathrm{MS}+1.5 \mathrm{mg} \mathrm{l}^{-1} \mathrm{IAA}+0.3 \mathrm{mg} \mathrm{l}^{-1}$ $\mathrm{kin}+1 \mathrm{~g} \mathrm{l}^{-1} \mathrm{CH}, \mathrm{T}_{16} \mathrm{MS}+2.0 \mathrm{mg} \mathrm{l}^{-1} \mathrm{IAA}+0.3 \mathrm{mg} \mathrm{l}^{-}$ ${ }^{1} \mathrm{kin}+1 \mathrm{~g} \mathrm{l}^{-1} \mathrm{CH}$.

Statistical analysis: The observations recorded were statistically analyzed by subjecting the data to Factorial Completely Randomized Design, designed by (Gomez and Gomez, 1984). Level of significance was determined by using standard analysis of variance. Differences among mean values were assessed by LSD. The data obtained with per cent values were subjected to arc sine transformation.

\section{RESULTS AND DISCUSSION}

Effect of hormones on callus induction: Auxins were used to induce cell division and root differentiation in tissue culture medium. Among them, 2,4-D is widely used for callus induction. In the present study, MS medium containing $1.0 \mathrm{~g} \mathrm{l}^{-1}$ casein hydrolysate was supplemented with various levels of 2,4-D viz., 0.5, $1.0,1.5$ and $2.0 \mathrm{mg} \mathrm{l}^{-1}$ and also IAA at $0.5,1.0,1.5$ and $2.0 \mathrm{mg} \mathrm{l}^{-1}$ combination with cytokinin (kinetin). A differential influence of various concentrations of 2,4D, IAA in callus behaviour was observed. Addition of adequate levels of synthetic auxins such as 2,4-D in to a basal medium resulted in prolific callus formation in maize tissue culture. Callus could not be induced in $\mathrm{N}_{6}$ medium in the absence of 2,4-D (Binott et al., 2008). The influence of different concentration of 2,4-D, IAA alone or in combination with $0.3 \mathrm{mg}^{-1}$ kinetin were recorded maximum, callus induction percentage, number of days for callus induction and fresh weight of callus on $28^{\text {th }}$ day. This is in accordance with the findings of Ansari (1997) and Shohael et al. (2003) in maize. The complex action of kinetin was observed by Inoue and Maeda (1982) in rice. They explained the effect of kinetin on callus induction could be promotive or inhibitory depending upon the kind and concentration of auxin in the medium.

In the present study, MS medium containing $1.0 \mathrm{~g} \mathrm{l}^{-1}$ Casein Hydrolysate has been added with different levels of kinetin viz., $0.1,0.2$ and $0.3 \mathrm{mg} \mathrm{l}^{-1}$ in combination with auxin 2,4-D and IAA. The result showed that among different concentrations tried, $0.3 \mathrm{mg} \mathrm{l}^{-1}$ kinetin recorded higher values $(60.44 \%)$ of callus induction per cent when compared to other levels. Since kinetin is susceptible to interactions with $2,4-\mathrm{D}$, there was variation in response. But when $0.3 \mathrm{mg} \mathrm{l}^{-1}$ of kinetin was combined with $2,4-\mathrm{D} 1.5 \mathrm{mg} \mathrm{l}^{-1}\left(\mathrm{~T}_{7}\right)$, IAA $1.5 \mathrm{mg}$ $1^{-1}\left(\mathrm{~T}_{15}\right)$ recorded the higher values when compared to either 2,4-D or IAA alone. Similar results reported by Shohael et al. (2003), embryogenic calli formation was high when $\mathrm{N}_{6}$ medium supplemented with L-Proline $2.3 \mathrm{~g} \mathrm{l}^{-1}$, casein hydrolysate $200 \mathrm{mg} \mathrm{l}^{-1}, 2,4-\mathrm{D} 1.0 \mathrm{mg} \mathrm{l}^{-}$ 1 and Kinetin $0.1 \mathrm{mg} \mathrm{l}^{-1}$. Abebe et al. (2008) also reported, when $3 \mathrm{mg} \mathrm{l}^{-1}$ of 2,4-D was combined with $0.5 \mathrm{mg} \mathrm{l}^{-1}$ kinetin recorded highest callus induction per cent. Among the genotypes the maximum percentage of callus induction was recorded by $\mathrm{CO} \mathrm{H} \mathrm{(M)} 5$ (59.61\%) followed by UMI $285(56.96 \%)$ and UMI $757(55.25 \%)$. The maximum percentage of callus induction response was recorded by seed followed by immature embryo the explants leaf bits recorded the poorest response for callus induction. Among the 16 treatments studied, T7 showed the maximum of $60.44 \%$ followed by T15 (56.79\%) and T16 (56.33\%) (Table 1).

Among the $\mathrm{G} \times \mathrm{E}$ interactions, the maximum callus induction percentage was observed in $\mathrm{G}_{4} \mathrm{E}_{1}(99.50 \%)$ followed by $\mathrm{G}_{5} \mathrm{E}_{1}(99.20 \%)$ and $\mathrm{G}_{1} \mathrm{E}_{1}(98.46 \%)$ with the treatment of $\mathrm{T}_{15}(\mathrm{MS}+1.5 \mathrm{mg} / 1 \mathrm{IAA}+0.3 \mathrm{mg} / 1$ $\mathrm{K}+1 \mathrm{~g} / \mathrm{l}(\mathrm{H})$. The treatment $\mathrm{T}_{12}$ showed poor performance in all the explants and in all the genotypes. Among the treatment combination $\mathrm{G}_{4} \mathrm{E}_{1} \mathrm{~T}_{15}$ recorded the maximum value of $(99.50 \%)(9.20 \%)$ and (98.46\%) for the genotypes COH (M) 5, UMI 285 and UMI 757 respectively. The genotypes UMI 615 and CO 1 had a slightly lower value compared to the other genotypes. 
๘)

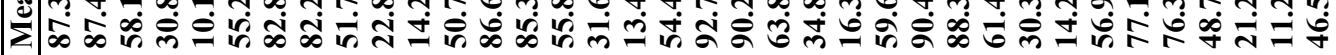

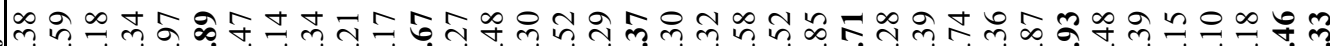

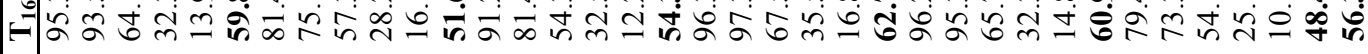

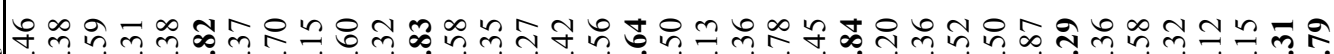

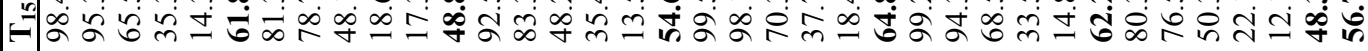

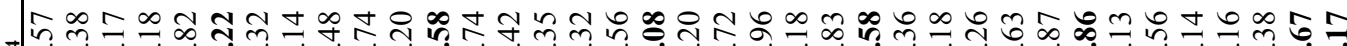

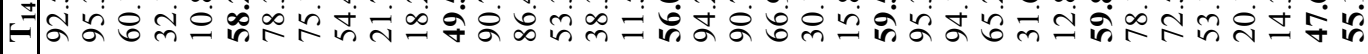

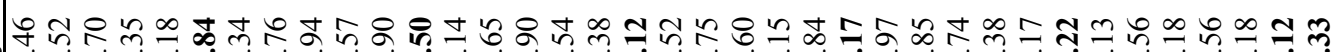

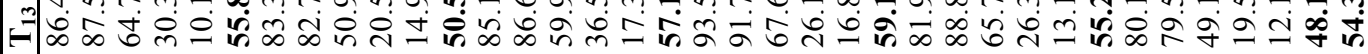

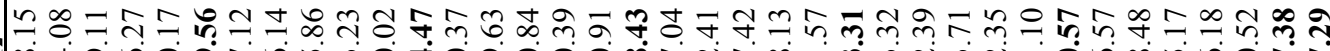

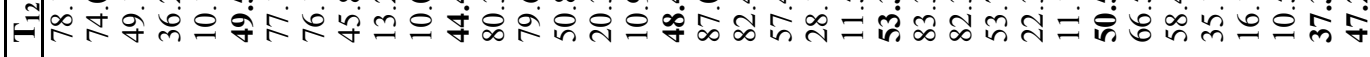

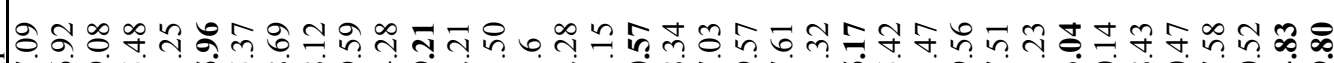

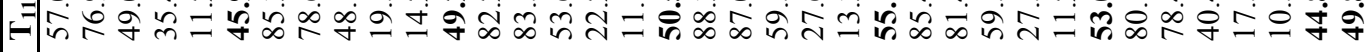

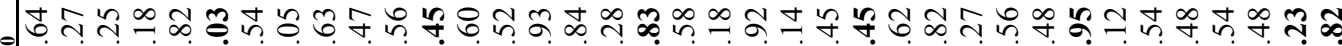

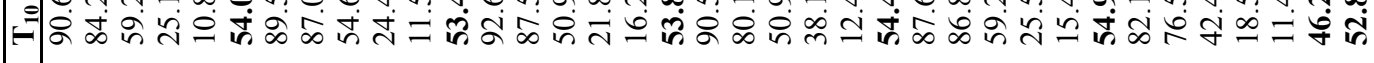

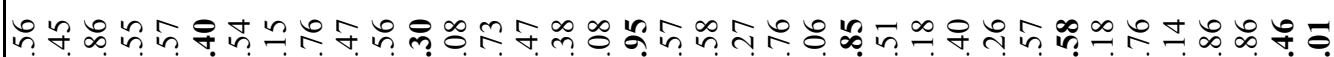

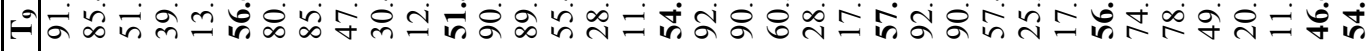

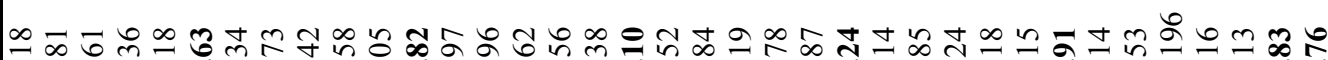

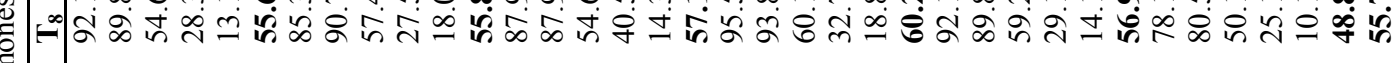

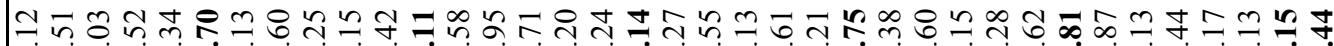
Fڤ \&

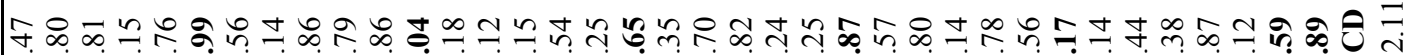

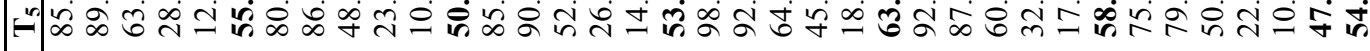

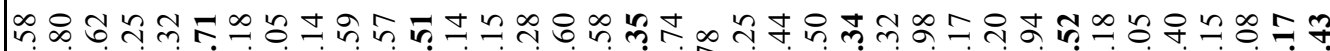

แ में

ำ 운

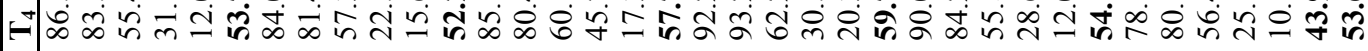

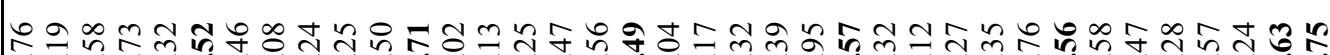

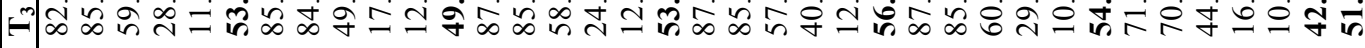

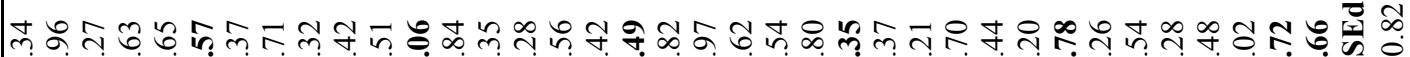

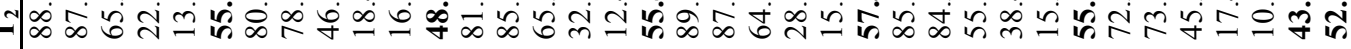

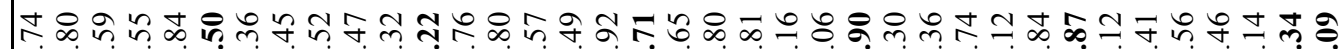

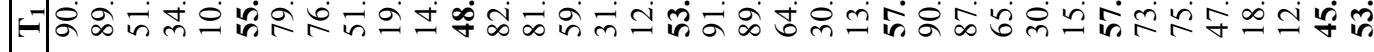

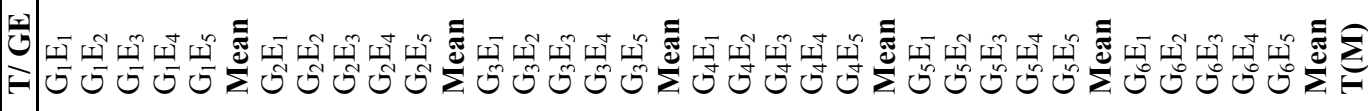




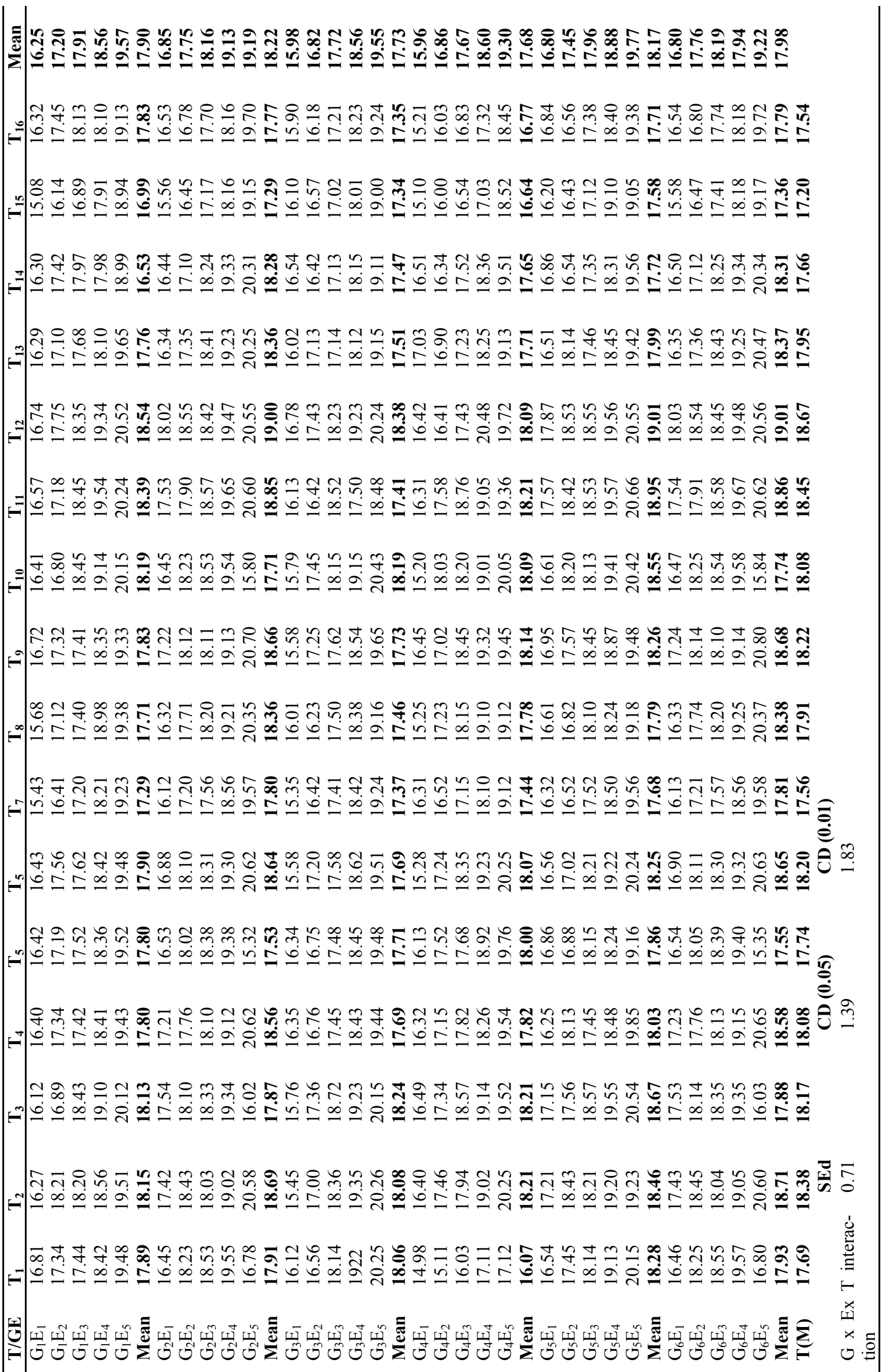


N. Malini et al. / J. Appl. \& Nat. Sci. 10 (1): 202 - 209 (2018)

|

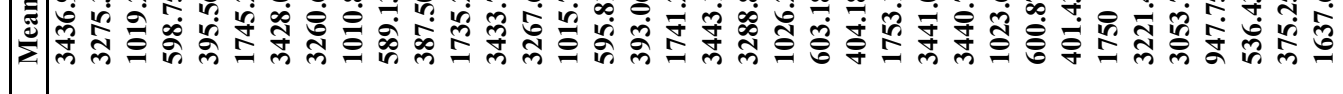

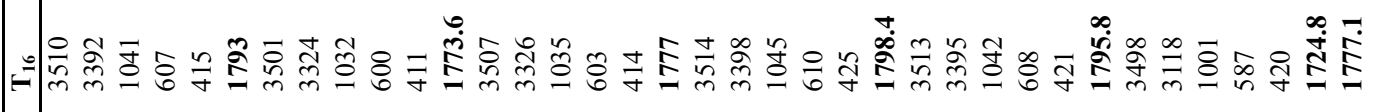

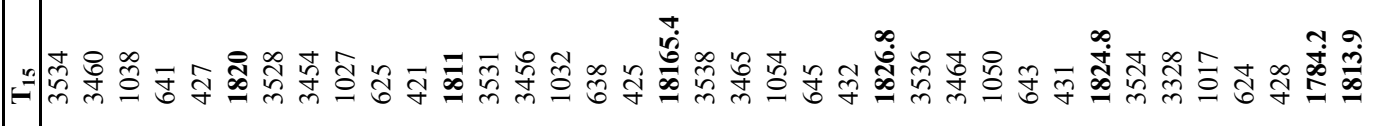

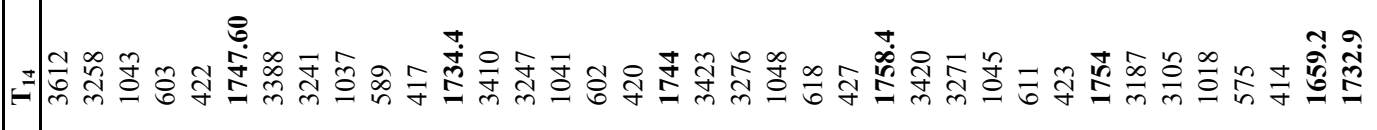

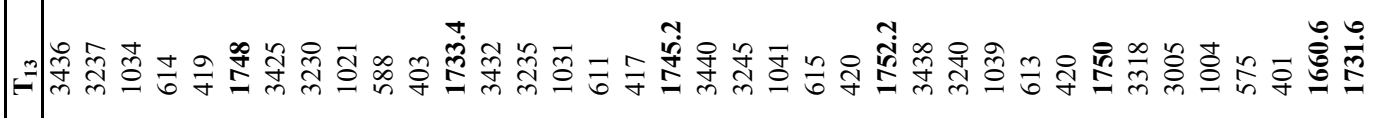

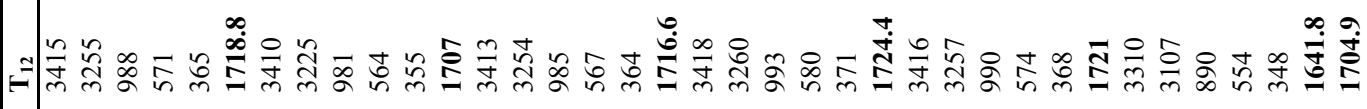

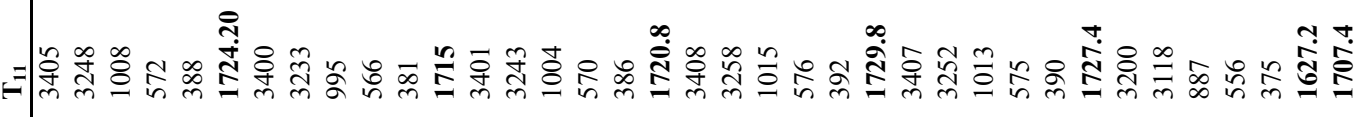

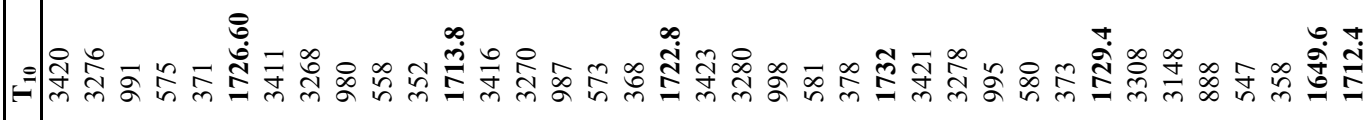

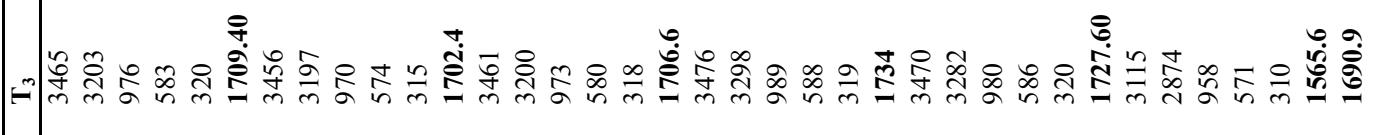

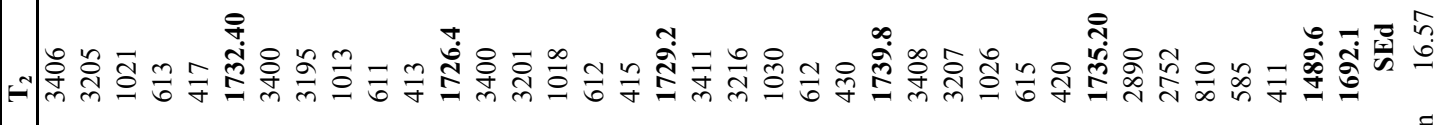
$==$ = 
Effect of explant: In the present study, investigations were made using five explants seed (E1), immature embryo (E2), leaf bits (E3), root (E4) and hypocotyls (E5). These explants were cultured with various levels of hormones and organic supplements and variation in their capacity in callus response was studied.

The studies indicated that maximum percentage of callus induction response was observed in seed followed by immature embryo and leaf bit recorded the poorest response of callus induction. Similar results were already reported by Shohael et al. (2003) in maize. The high callus responding nature and culturability of mature seed was in accordance with the reports of Delporte et al. (2001) in wheat and Bijy (2002) in rice. Al-Abed et al. (2006) and Sikandar et al. (2007) reported that the mature seed scutellum is the best explant for high totipotent embryogenic callus initiation and they also reported that the plant regeneration from coleoptile and root segments was unsuccessful. The high culturability of immature embryo was in agreement with the reports of Oduor et al. (2006). Benson, (2000) and Huang and Wei (2004) reported the juvenile tissues are usually more responsive to tissue culture than mature ones.

In the present study, studies regarding explants performance immature embryo as well as seed was more (or) less similar and best. Hypocotyl, root and leaf bits were lagging behind and the poor response of leafbits was also reported by Vinothini (2004) in rice. Chand and Sahrawat (2000) reported high callus induction and plant regeneration using root explants of barley. In contrast, Khaleda and Al-Forkan (2006) reported that root explant showed poor response be due to the fact that the calli derived from those explants were not totipotent for plant regeneration in rice.

Number of days for callus induction (days): In callusing duration studies, for early callus induction inferred that the use of $1.5 \mathrm{mg} \mathrm{l}^{-1}$ IAA in combination with $0.3 \mathrm{mg} \mathrm{l}^{-1}$ kinetin $\left(\mathrm{T}_{15}\right)$ followed by $2.0 \mathrm{mg} \mathrm{l}^{-1}$ IAA $+0.3 \mathrm{mg} \mathrm{l}^{-1}$ kinetin $\left(\mathrm{T}_{16}\right)$ and $1.5 \mathrm{mg} \mathrm{l}^{-1} 2,4-\mathrm{D}+$ $0.3 \mathrm{mg} \mathrm{l}^{-1}$ kinetin $\left(\mathrm{T}_{7}\right)$ was the best. Among the explants, seed recorded the earlier induction of callus followed by immature embryo. The leaf bit recorded maximum days for callus induction.

Among the genotypes the earlier induction of callus was observed in $\mathrm{CO} \mathrm{H}(\mathrm{M}) 5\left(\mathrm{G}_{4}\right)$ (17.68 days) followed by UMI $285\left(\mathrm{G}_{5}\right) 17.73$ days. CO $1\left(\mathrm{G}_{6}\right)$ recorded the maximum days for callus induction (18.22). The influence of genotypes on callus induction in maize was reported already by Green and Philips, (1975) and Tomes and Smith, (1985). Bronsema et al. (1997) indicated that the genetic information needed for embryogenic callus formation of A 632 as female parent, was transferred through A 188 pollen. The results revealed that among the explants, seed $\left(E_{1}\right)$ recorded the earlier induction of callus (16.22 day) followed by immature embryo $\left(\mathrm{E}_{-2}\right)$. The leaf bit explant took maximum days for callus induction (19.27 days). Among the $\mathrm{G} \times \mathrm{E}$ interactions, $\mathrm{G}_{1} \mathrm{E}_{1}, \mathrm{G}_{4} \mathrm{E}_{1}, \mathrm{G}_{2} \mathrm{E}_{1}$ recorded the earlier days with $\mathrm{T}_{15}(\mathrm{MS}+1.5 \mathrm{mg} / 1 \mathrm{IAA}+0.3 \mathrm{mg} / 1 \mathrm{~K}+30 \mathrm{~g} / \mathrm{l}$ maltose) 15.08 days, 15.10 days and 15.56 days respectively. The interactions $\mathrm{G}_{6} \mathrm{E}_{5}$ with $\mathrm{T}_{9}$ recorded longer days for callus induction (20.80 days). The results on number of days for callus induction for the hormonal combination revealed significant 1.39 differences among the treatments. MS + $1.5 \mathrm{mg} / 1 \mathrm{IAA}+$ $0.3 \mathrm{mg} / 1 \mathrm{~K}+30 \mathrm{~g} / 1$ maltose $\left(\mathrm{T}_{15}\right)$ treatment recorded the minimum number of days for callus induction 17.20 days followed by $\mathrm{T}-{ }_{12}$ (18.67 days) (Table 2 ).

Under various levels of organic supplements, significantly superior callus induction per cent on immature embryo was noticed in $\mathrm{CO}$ H (M) 5, UMI 285 and UMI 757 when compared to other types. Study in seed emphasized the capacity of CO H (M) 5 and UMI 285 with higher per cent values and indicated its superiority over other genotypes. Similarly CO H (M) 5 and UMI 285 genotypes showed significant values in the case of root and hypocotyl, where as other genotypes stood inferior. When study was conducted on duration of callusing, minimum number of days was observed for immature embryo in CO H (M) 5, UMI 285 and UMI 757 when compared to other genotypes. Seed culture confirmed again minimum duration induction for $\mathrm{COH}$ (M) 5 followed by UMI 285 and UMI 112 and they stood superior to other genotypes. In the case of root and hypocotyl, significantly higher values were noticed in $\mathrm{COH}$ (M) 5 followed by UMI 112 as compared to others.

In all the above studies, $\mathrm{COH}(\mathrm{M}) 5$ was performing extremely well under all treatments. This can be attributed to its already high responding nature and it is a tissue culture friendly type. UMI 285, UMI 757, UMI 112, UMI 615 and CO 1 also high response, where as CO 1 lagged behind all treatments. Such type of varietal variation to culture response was reported by other researchers Hodges et al. (1986) in maize, Bronsema et al. (1997) in maize Agarwal et al. (2006) in rice and Binott et al. (2008) in maize.

Fresh weight of callus on $\mathbf{2 8}^{\text {th }}$ day (mg): Callus fresh weight on $28^{\text {th }}$ day, significantly superior at $T_{15}(1.5$ $\mathrm{mg} \mathrm{l}^{-1}$ IAA) followed by $\mathrm{T}_{16}\left(2.0 \mathrm{mg} \mathrm{l}^{-1}\right.$ IAA) and $\mathrm{T}_{7}$ (1.5 $\mathrm{mg} \mathrm{l}^{-1}$ 2,4-D) (Table 20). Among the five explants, seed recorded maximum fresh weight of callus followed by immature embryo. This was in agreement with the report of Ansari, (1997), he cultured on 2,4-D ranged from $1.5 \mathrm{mg} \mathrm{l}^{-1}$ to $2.0 \mathrm{mg} \mathrm{l}^{-1}$ with different media viz., (MS) Murashige and Skoog, $\left(\mathrm{N}_{6}\right) \mathrm{Chu},\left(\mathrm{B}_{5}\right)$ Gamborg B5 Medium, (YP) Yeast Media and (LS) Linsmaier and Skoog Medium. Callus induction was high in (MS) Murashige and Skoog and $\left(\mathrm{N}_{6}\right)$ Chu medium when compared to other media, which was due to the differences on major nutrients present in these basal media.

Among the genotypes, the maximum callus weight was 
observed in $\mathrm{COH}(\mathrm{M}) 5\left(\mathrm{G}_{4}\right) 1753.13 \mathrm{mg}$ followed by UMI $285\left(\mathrm{G}_{5}\right)(1750 \mathrm{mg})$ and UMI $757\left(\mathrm{G}_{1}\right)(1745.2$ $\mathrm{mg})$. The genotype $\mathrm{CO} 1\left(\mathrm{G}_{6}\right)$ recorded the minimum callus weight of $1444.62 \mathrm{mg}$. The results revealed that among the explants, the seed explant $\left(E_{-1}\right)$ recorded the maximum weight of $3400.73 \mathrm{mg}$ followed by immature embryo $\left(E_{2}\right) 3264.51 \mathrm{mg}$. The leaf bit explant (E5) had minimum fresh weight $392.83 \mathrm{mg}$. The results of fresh weight on $28^{\text {th }}$ day of the hormonal combination revealed significant differences among the treatments. The treatments $\mathrm{T}_{15}(\mathrm{MS}+1.5 \mathrm{mg} / 1 \mathrm{IAA}+0.3$ $\mathrm{mg} / 1 \mathrm{~K} 30 \mathrm{~g} / 1$ maltose), $\mathrm{T}_{16^{-}}(\mathrm{MS}+2.0 \mathrm{mg} / 1 \mathrm{IAA}+$ $0.3 \mathrm{mg} / 1 \mathrm{~K}+30 \mathrm{gl} /$ maltose $)$ and $\mathrm{T}_{7}(\mathrm{MS}+1.5 \mathrm{mg} / 1$ $2,4 \mathrm{D}+0.3 \mathrm{mg} / 1 \mathrm{~K}+30 \mathrm{~g} / 1$ maltose) recorded the maximum weight of $1813.9 \mathrm{mg}, 1777.1 \mathrm{mg}$ and 1744.2 $\mathrm{mg}$ respectively. The treatment $\mathrm{T}_{3}$ recorded the minimum weight of callus $(1690.90 \mathrm{mg}$ ). Among the $\mathrm{G} x$ $E$ interactions $G_{4} E_{1}$ recorded the maximum weight of $3443.13 \mathrm{mg}$, followed by $\mathrm{G}_{5} \mathrm{E}_{1}(3441.06 \mathrm{mg})$ and $\mathrm{G}_{5} \mathrm{E}_{2}$ (3440.75 mg). The treatment combination $\mathrm{G}_{6} \mathrm{E}_{5}, \mathrm{G}_{2} \mathrm{E}_{5}$, $\mathrm{G}_{3} \mathrm{E}_{5}$ recorded the minimum weight of $375.25 \mathrm{mg}$, $387.50 \mathrm{mg}$ and $3930.06 \mathrm{mg}$ respectively (Table 3 ).

Among the $\mathrm{G} \times \mathrm{E} \times \mathrm{T}$ interactions $\mathrm{G}_{4} \mathrm{E}_{1} \mathrm{~T}_{15}$ recorded the maximum weight of callus $(3538 \mathrm{mg})$ followed by $\mathrm{G}_{5} \mathrm{E}_{1} \mathrm{~T}_{15}$ (3536 mg). The treatments $\mathrm{G}_{6} \mathrm{E}_{5} \mathrm{~T}_{9}, \mathrm{G}_{6} \mathrm{E}_{5} \mathrm{~T}_{3}$ and $\mathrm{G}_{2} \mathrm{E}_{5} \mathrm{~T}_{3}$ recorded the minimum of callus of 280 $\mathrm{mg}, 310 \mathrm{mg}$ and $315 \mathrm{mg}$ respectively. Among the $\mathrm{G} \mathrm{x}$ E $x$ T interactions $G_{1} E_{1} T_{15}$ recorded the minimum value of 15.02 days followed by $\mathrm{G}_{-4} \mathrm{E}_{1} \mathrm{~T}_{15}$ (15.10 days), while the treatment combination $\mathrm{G}_{6} \mathrm{E}_{5} \mathrm{~T}_{9}$ recorded the maximum number of days for callus induction (20.80 days).

\section{Conclusion}

Transformation of maize plants was made successfully by standardization of tissue culture experiments. The study concluded that $0.3 \mathrm{mg} / 1$ of kinetin combined with $1.5 \mathrm{mg} / 1$ 2,4-D and $1.5 \mathrm{mg} / 1 \mathrm{IAA}$ has recorded highest callus induction percentage. The genotypes $\mathrm{COH}(\mathrm{M}) 5$ with Immature embryo as a explant exhibited earlier callus induction and maximum callus weight. These optimized tissue culture protocol, will be used for transformation of resistance to biotic and abiotic stress in maize in future.

\section{REFERENCES}

Abebe, Z. D., Teffera, W., and Machuka, J. S. (2008). Regeneration of tropical maize lines (Zea mays L.) from mature zygotic embryo through callus initiation. African Journal of Biotechnology Vol. 7 (13): 2181-2186.

Agarwal, P. K., Gosal, S. S., and Sidhu, G. S. (2006). Sequential reduction of 2, 4-D improves whole plant regeneration from long term maintained calli in some indica cultivars of rice. Oryza, 43 (1): 10-15.

Ahmadabadi, M., Ruf, S., and Bock, R.(2007). A leaf-based regeneration and transformation system for maize. Transgenic Res., 16: 437-448.

Al-Abed, D., S. Rudrabhatla, R. Jalla and S. Goldman. 2006.
Spilt - seed: a new tool for maize researchers. Planta. $223: 1355-1360$.

Ansari, N. A., (1997). Tissue culture studies in maize (Zea mays L.) Ph.D. (Ag.) Thesis, TNAU, Coimbatore.

Benson, E. E.,(2000). In vitro plant recalcitrance: An introduction. In vitro Cell Dev. Biol. 26: 141-148.

Bijy. K. R., (2002). In vitro screening for drought tolerance in rice (Oryza sativa L.) M.Sc., (Ag.) Thesis, TNAU, Coimbatore.

Binott, J. J., Songa, J. M., Ininda, J., Njagi, E. M. and Machuka, J. (2008). Plant regeneration from immature embryos of Kenyan maize in bread lines and their respective single cross hybrids through somatic emrbyogenic. African Journal of Biotechnology, Vol. 7(8): 981 $-987$.

Bronsema, F. B. B., Van Oostveen, W.J.F. and Van Lammeren, A.A.M. (1997). Comparative analysis of callus formation and regeneration on cultured immature maize embryos of the in bred lines A188 and A 632. Plant Cell, Tissue and Organ Culture., 50: 57-65.

Chand, S. and Sahrawat, A. K. (2000). Efficient plant regeneration from root callus tissues of barley (Hordeum vulgare L.). J. Plant Physiol., 156 : 401-407.

Delporte, F., Mostade, O. and Jacquemin, J.(2001). Plant regeneration through callus initiation from thin mature embryo fragments of wheat. Plant Cell Tissue Organ Cult., 67: 73-80.

Devi, S., PArimala, K., Sravanthi, K. (2016). Gene action and combining ability analysis for yield and its component traits in maize and its component traits in maize (Zea mays L.) Bioscan. (2): 1043 - 1047.

Gomez, K. A. and Gomez, A. A. (1984). Statistical procedures for Agricultural Research. John Wiley and Sons. Inc., New York. pp. 680.

Green, C.E. and Philips, R. C. (1975). Plant regeneration from tissue cultures of maize. Crop Sci., 15: 417-421.

Hodges, T. K., Kamo, K. K., Imbrie, C. W., and Backwar, M. R.(1986). Genotype specificity of somatic embryogenic and regeneration in maize. Biotechnol., 4:219223.

Huang, X. Q and Wei, Z. M. (2004). High frequency plant regeneration through callus initiation from mature embryos of maize. Plant Cell Rep., 22: 793-800.

Inoue, M and Maeda, E. (1982). Control of organ formation in rice callus using two step culture method. In : Plant Tissue Culture (ed.) Fujiwara, A., Maruxen, Tokyo, pp. 183-184.

Khaleda, L. and Forkan, M.Al. (2006). Genotypic variability in callus induction and plant regeneration through somatic embryogenesis of five deepwater rice (Oryza sativa L.) cultivars of Bangladesh. African J. Biotech., (5): pp-1435-1440.

Murashige, T. and Skoog, F. (1962). A revised medium for rapid growth and bioassay with tobacco tissue cultures. Physiol. Plantarum., 15: 473-497.

Oduor, R. O., Njagi, E. N. M., Ndung'u, S. and Machuka, J. S. (2006). Invitro regeneration of Dryland Kenyan Maize Genotypes through somatic embryogenesis. International Journal of Botany., 2(2): 146-151.

Omer, R. A., Ali, A. M., Matheka, J. M. and Machuka, J. (2008). Regeneration of Sudanese maize in bred lines and open pollinated varieties. African Journal of Biotechnology, Vol. 7(11): 1759-1764. 
Shohael, A. M., Akanda, M. A. L., Parvez, S. and Mahfuja, S.(2003). Somatic embryogenesis and plant regeneration from immature embryo derived callus of inbred maize (Zea mays L.). Biotech., 2 (2): 154-161.

Sikandar, W., Ali, Khan, I. and Munir, I. (2007). Optimization of invitro conditions for Callus induction, proliferation and regeneration in wheat (Triticum aestivum L.) Cultivars. Biotech., 6(3): 420-425.
Tomes, D. T., and Smith, O. S. (1985). The effects of parental genotype on isolation of embryogenic callus from elite maize germplasm. Theor. Appl. Genet., 70:505509

Vinothini, S., (2004). Enhancement of variability in drought tolerant varieties of rice (Oryza sativa L.) Through in vitro mutagenesis. M.Sc. (Ag.) Thesis, A. C \& R. I., Killikulam, TNAU, Coimbatore. 